\title{
Adoption and Utilisation of Information and Communication Technologies (ICTs) for e-Commerce among Kano based Traders
}

\author{
Salisu Dahiru ${ }^{1}$, Ali Garba ${ }^{2}$, Usman Hassan ${ }^{3}$ \\ 1Department of Library and Information Science Ahmadu Bello University (ABU), Zaria. Kaduna State \\ Nigeria, \\ 2Kashim Ibrahim Library, Ahmadu Bello University (ABU), Zaria, Kaduna State, Nigeria, 3. Collection \\ Development Division, University Library. Kano State University of Science and Technology, Wudil, Kano State \\ Nigeria,
}

\begin{abstract}
The effective implementation of cashless policy depends to the large extent upon the traders' level of adoption and utilisation of various ICTs for e-commerce. In view of this, the study investigated the level of adoption and utilization of various ICTs for e-commerce among Kano based traders. It was guided by three research objectives: to determine the extent to which Kano based traders adopt ICTs for e-commerce, to investigate how Kano based traders utilize ICTs for e-commerce and to determine how useful the ICTs are for e-commerce to Kano are based traders. Survey research method was adopted for the study. The population of the study comprised of traders conducting their trading activities in three major markets within Kano metropolis namely: Abubakar Rimi, Singer and Kwari Markets. These are summed up to 32,624 traders. One percent of the population (326) was randomly selected from each of the three markets as the sample of the study. Questionnaire was used as an instrument for data collection, 265 questionnaires representing (81.28\%) were successfully retrieved and analysed using descriptive statistics such as frequency tables, pie-charts and barcharts. The study revealed that, smart phone is the highest adopted ICT for e-commerce (97\%), as ECC and POS are the least adopted ICTs for e-commerce with only (4.5\%). The study also shows that there is low utilization of ICTs for e-commerce, smart phone has the highest utilization among Kano based traders with response rate of $69(26 \%)$ for e-payment, 58 (22\%) for e-sale and $52(19.6 \%)$ and $35(13.2 \%)$ for sending and receiving purchase order respectively. Internet recorded the least utilized with response rate of $6(2.3 \%)$ for esale and 12 (4.5\%) each for sending and receiving purchase order. The study also discovered that ICTs for ecommerce are useful; they make the commerce to be secured, convenient, cheaper etc. Based on the major findings of the study, recommendations were made on how to improve the adoption and utilization of ICTs for ecommerce: Mass literacy campaign should be extended to traders, who cannot read and write, as the Literate ones should be encouraged to go for computer training. Ministries of commerce in conjunction with Central Bank of Nigeria and traders' unions should organize Training workshops periodically, to both traders and consumers, on how to utilize and adopt various ICTs for e-payment, e-sale, sending and receiving purchase order among others.
\end{abstract}

Key Words: Adoption, e-Commerce, Information and Communication Technologies, Traders, Utilisation

\section{Introduction}

The need to exchange goods and services among people brought about commerce. Settle (2000) defined commerce as negotiated exchange of valuable objects or services between two or more parties and include all activities that each of the parties undertake to complete the transaction. Commerce was classified using different criteria. From methodology perspectives, Christopher (2011) classified commerce into traditional and electronic commerce respectively. According to him, traditional commerce involves face-to-face appearance between a buyers and a seller, the nature of the products can be felt or touched and accessible within a limited time. Electronic commerce on the other hand, is screen-to-face customer interface, accessible for $24 \mathrm{hrs}$ a day, and involving one-to-one customization.

Information and Communication Technology (ICT) is made up of two basic components; the information technology (IT) which refers to the creation, storage and processing of data through the use of computers and other microelectronics and the communication technology (which include the internet and telecommunication technology). According to World Bank (2002) ICT consists of hardware, software, networks and media for collection, storage, processing transmission and presentation of information.

The rapid development of ICT and the Internet in the last three decades have opened a new business methodology called e-commerce; World Trade Organisation (2013) defined e-commerce as the sale or purchase of goods or services conducted over computer networks by methods specifically designed for the purpose of receiving or placing of orders. Even though goods or services are ordered electronically, the payment and the 
ultimate delivery of the goods or services do not have to be conducted online. An e-commerce transaction can be between enterprises, households, individuals, governments, and other public or private organizations. Included in these electronic transactions are orders made over the web, extranet or electronic data interchange. The type of transaction made is defined by the method of placing the order. Normally excluded are orders made by telephone calls, fax or manually typed e-mails. Tuban. Lee and chung (2000) described e-commerce as electronic transaction involving buying and selling of products, services and information over network (usually internet). This form of commerce is applicable in many ways. Hellestein (2002) stressed that e-commerce can be applied for e-procurement, online catalogs; sales of online computer software, online sell of photographs, security trading, offshore banking, online registration e.t.c.

\section{Statement of the Problem}

The world is changing in a jet speed due to advances in science and technology; particularly the development of ICTs and the Internet in the last three decades provided an enabling environment for a new business methodology known as e-commerce and also transformed many countries of the world into cashless society. Recently, Central Bank of Nigeria (2014) introduced the cashless policy in all states of the federation. This increases the need for all Nigerians, especially traders to adopt and utilize various ICTs for their business transactions. In view of this, the study investigates the level of adoption and utilization of various ICTs for ecommerce among Kano based traders.

\section{Objectives of the Study}

The study is designed to achieve the following objectives:

$>$ To determine the extent to which Kano based traders adopt ICTs for e-commerce.

$>$ To investigate on how Kano based traders utilize ICTs for e-commerce.

$>$ To find out how useful are the ICTs for e-commerce to Kano based traders

\section{Literature Review}

There are numerous ICTs used for e-Commerce. GSPAY (2012) have identified the following ICTs used for e-commerce: Electronic Data Interchange (EDI) Internet, fax machine, e-mail smart card, Automated Teller Machine (ATM), Electronic Payment System (EPS) and Electronic Fund Transfer (EFT). Humphrey et.al (2003) identified smart phone, Worldwide Web (WWW), Encrypted Credit Card, debit card and videoconferencing as ICTs for e-commerce.

According to Angel (2008), EDI is the oldest method of exchanging business information and electronic transaction among enterprises connected via Local Area network. Exforsys (2012), described EDI as fast and efficient way to exchange information currently. It is used to order goods and for e-sales. The backbone of all ICTs used for e-commerce is internet. Ssewanyana and Busler (2007) described internet as the ICT that host most e-commerce technologies and gives forms or individual consumers room for placing order with suppliers, completion of form etc. According to Egan (2011), Internet is the enablers of e-commerce as it allows businesses to show case and sell their products and services online. It also gives potential customers and business partners access to information about businesses and their products and services that may lead to purchase. A technology integrated with Internet called World Wide Web (WWW). HealthCote (2002) regarded WWW as a technology which forms or companies use to deliver information regarding their products and services and also use to sell their products and services. Seatini (2004) pointed out that lack of human capacity and skills to use technology are among the barriers hindering the use of ICTs in developing countries.

Many traders all over the world have adopted various ICTs in their business transactions, though, the level of adoption varies from one part of the world to the other and from one category of business to the other. In developed countries of the world, adoption of ICTs for e-commerce is higher compared to developing countries. The result of a survey conducted by United Kingdom office of National Statistics (UKONS) (2011) revealed that, in the year 2010, the largest businesses, characterized by 1000 and above employees continue to lead the way in adoption of new technologies. However, their small businesses counterparts were closing the gap with increasing number adopting fixed broadband and mobile ( $3^{\text {rd }}$ generation) Internet and websites. In a related development, the adoption of ICTs for e-commerce among advanced developing countries of the world is growing rapidly. Idenscat (2012) released that $82 \%$ of enterprises in Austria had a website, and nearly all large enterprises have websites, $92 \%$ of medium size enterprises and $80 \%$ of small enterprises present their companies and their products via websites.

Adoption of ICTs for e-commerce in developing countries of the world is very limited. The report released by United Nations Conference on Trade and Development (UNCTAD) (2003) revealed that, there was no figure on e-commerce in developing countries. The only statistics available according to the report was in the adoption of Internet though Internet is prerequisite for e-commerce, no number of users that exploited or adopted Internet for trading activities recorded. Evaluating the prospect of e-Commerce in Nigeria, it was 
observed that virtually all the companies assessed in Nigeria had online presence but with little or no commercial activities taking place (Ayo, 2006). Contrary to this, Ssewanyana and Busler (2007) revealed that in Uganda, all firms covered by the survey adopted ICTs like computer and Internet and $62 \%$ of them had web presence in the Internet.

As in the case of adoption of various ICTs for e-commerce, the utilization of ICTs for e-commerce also varies from one part of the world to the other and from one category of business to the other. Though, developed countries are at the fore-front in general utilization of ICTs for e-commerce, the proportion of sales using ICTs like websites is lower compares to traditional method of bricks-and mortar. Based on a survey conducted by UKONS (2011) revealed that the value of website sales as proportion to total sales in UK was only $4.2 \%$ in the year 2009 and 2010. The survey carried out by UKONS (2011) also revealed that, wholesale sector had highest percentage of sales using website with sales value of $£ 375$ billion, while retail sector had only $£ 12.8$ billion in the year 2010. Utilization of ICTs for e-commerce in the part of advanced developing countries is growing rapidly in recent years. The survey conducted by Ghorish (2009) revealed that business-to-business e-commerce existed among large scale industries in Iran using internet, WWW and EDI-type message for transforming business information. As in the case of adoption of ICTs for e-commerce, less developed countries are also lagged behind in general utilization of ICTs for e-commerce. UNCTAD (2003) declared that, only a handful of the total e-commerce transactions are from developing countries.

Electronic commerce is now an alternative and convenient way of conducting business both nationally and internationally, it continued to be a catalyst to accelerate economic growth in many developed countries around the world such as Singapore, Denmark, Swiserland, United States of America, China, just to mention but a few (Akintola, Akinyede and Agbonifo, 2011). It is believed that, e-commerce has many advantages over the traditional method of commerce. Oliva (2011) disclosed that, the biggest attraction of e-commerce is that it is faster, convenient and money saving. Anyakoha (2005) pointed out that, e- commerce reduces cost of business transactions, as entrepreneurs wouldn't have to travel to certain distance before business transaction is carried out.

\section{Methodology}

The study adopted survey research method. The population of the study comprised of Kano based traders conducting their trading activities in the three major markets in Kano Metropolitan Area, which are summed up to 32,624 traders. Simple random sampling technique was adopted for each market. One percent of the traders were selected from each market, making the sample total of 326 traders. 104 traders from singer market, 152 traders from Abubakar Rimi Market, and 70 traders from Kantin- Kwari Market. Questionnaire was the instrument used for data collection. It was translated into 'Hausa' Language to enable the respondents, who cannot understand English Language to respond with ease. Data collected for the study was analyzed using frequency tables and other descriptive statistics (pie-chart and bar-chart).

\section{Findings and Discussion}

Fig.1: Extent of adoption of ICTs for e-commerce among Kano based traders

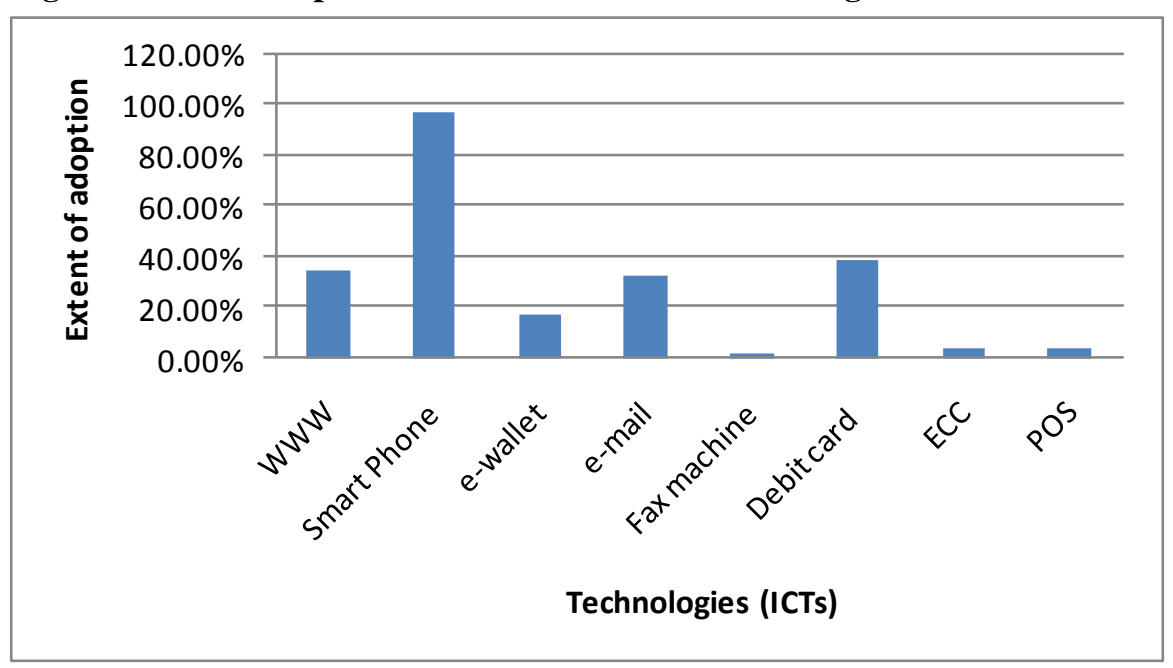

Looking at the above figure it clearly Shows that, smart phone recorded the highest adoption 259 (97.7\%), followed by debit card with 104 (39.2\%). Encrypted credit card and point-of-sale terminal recorded least adoption $12(4.5 \%)$ each. This finding is contrary to that of Ssewanyana and Busler (2007) who revealed 
that in Uganda, all firms covered by the survey adopted ICTs like computer and Internet and $62 \%$ of them had web presence in the Internet.

Table 1: utilization of ICTs for e-commerce among Kano based traders

\begin{tabular}{|c|c|c|c|c|c|c|c|c|c|c|c|c|c|}
\hline \multirow[t]{3}{*}{ (ICTs) } & \multicolumn{10}{|c|}{ Utilise for } & \multirow{2}{*}{\multicolumn{2}{|c|}{ Not utilise }} & \multirow[t]{3}{*}{ Total } \\
\hline & \multicolumn{2}{|c|}{ e-payment } & \multicolumn{2}{|c|}{ e-sale } & \multicolumn{2}{|c|}{ Sending order } & \multicolumn{2}{|c|}{ Receiving order } & \multicolumn{2}{|c|}{ Others } & & & \\
\hline & $\mathrm{F}$ & $\%$ & $\mathrm{~F}$ & $\%$ & $\mathrm{~F}$ & $\%$ & $\mathrm{~F}$ & $\%$ & $\mathrm{~F}$ & $\%$ & $\mathrm{~F}$ & $\%$ & \\
\hline ATM & 81 & 30.6 & - & - & - & - & - & - & - & - & 184 & 69.4 & 265 \\
\hline Smart phone & 69 & 26.0 & 58 & 21.9 & 52 & 19.6 & 35 & 13.2 & - & - & 51 & 19.2 & 265 \\
\hline e-mail & - & - & - & - & 12 & 4.5 & 12 & 4.5 & - & - & 241 & 91.0 & 265 \\
\hline $\begin{array}{l}\text { Video- } \\
\text { conferencing }\end{array}$ & - & - & - & - & - & - & - & - & 2 & 0.8 & 263 & 99.2 & 265 \\
\hline Internet & - & - & 6 & 2.3 & 12 & 4.5 & 12 & 4.5 & - & - & 235 & 88.7 & 265 \\
\hline Debit card & 29 & 10.9 & - & - & - & - & - & - & - & - & 236 & 89.1 & 265 \\
\hline E.C.C & 4 & 1.5 & - & - & - & - & - & - & - & - & 261 & 98.5 & 265 \\
\hline EDI & 6 & 2.3 & 6 & 2.3 & 6 & 2.3 & - & - & - & - & 247 & 93.2 & 265 \\
\hline EFT & 12 & 4.5 & - & - & - & - & - & - & - & - & 253 & 95.5 & 265 \\
\hline POS & 6 & 2.3 & 17 & 6.4 & - & - & - & - & - & - & 242 & 91.3 & 265 \\
\hline e-wallet & - & - & - & - & - & - & - & - & - & - & 265 & 100 & 265 \\
\hline WWW & 17 & 6.4 & 6 & 2.3 & - & - & - & - & - & - & 242 & 91.5 & 265 \\
\hline \multicolumn{14}{|l|}{ F.M } \\
\hline Others & - & - & - & - & - & - & - & - & - & - & 265 & 100 & 265 \\
\hline
\end{tabular}

Table 1 above revealed that, smart phone has the highest utilization among Kano based traders with response rate of $69(26 \%)$ for e-payment, $58(22 \%)$ for e-sale and $52(19.6 \%)$ and $35(13.2 \%)$ for sending and receiving purchase order respectively. ATM recorded second with $81(30.6 \%)$ utilization for making payment only. Internet recorded third with response rate of $6(2.3 \%)$ for e-sale and $12(4.5 \%)$ each for sending and receiving purchase order. At least utilization end, none of the respondents utilizes e-wallet for any transaction and only $2(0.8 \%)$ of the respondents utilized video-conferencing for other activities not identified. This low utilization of ICTs for e-transactions recorded is in line with UNCTAD (2003) declaration that, only a handful of the total e-commerce transactions are from developing countries.

Table 2: usefulness of ICTs for e-commerce to Kano based Traders

\begin{tabular}{|l|l|l|l|l|l|}
\hline Advantages & Reponses & No response & Total \\
\hline & Frequency & Percentage (\%) & Frequency & Percentage & \\
\hline It is faster & 133 & 50.2 & 132 & 49.8 & 265 \\
\hline It is more efficient & 69 & 26.0 & 196 & 74.0 & 265 \\
\hline It is convenient & 81 & 30.6 & 184 & 69.4 & 265 \\
\hline It is cheaper & 81 & 30.6 & 184 & 69.4 & 265 \\
\hline Other advantages & 6 & 2.3 & 259 & 97.7 & 265 \\
\hline Secured & 58 & 21.9 & 207 & 78.1 & 265 \\
\hline
\end{tabular}

Fig. 2 usefulness of ICTs for e-commerce to Kano based Traders:

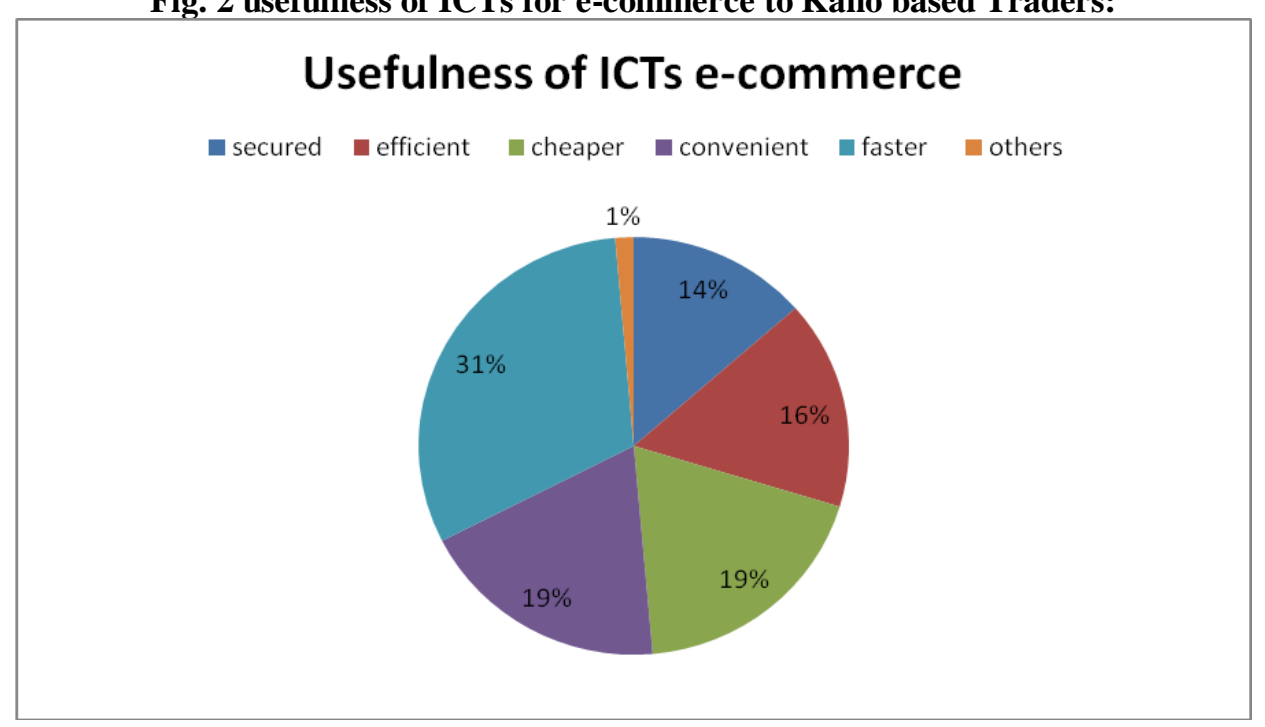

Table 2 and figure 2 above revealed that, $133(50 . \%)$ of the respondents believed that e-commerce is better than traditional commerce $81(30.6 \%)$ of the respondents believed that e-commerce is convenient and 
other $81(30.6 \%)$ believed that e-commerce reduces the cost of transactions compared to bricks-and-mortar method. These advantages identified above agreed with those identified by oliva (2011) and anykoha (2005) Oliva (2011) disclosed that, the biggest attraction of e-commerce is that it is faster, convenient and money saving. Anyakoha (2005) pointed out that, e- commerce reduces cost of business transactions, as entrepreneurs wouldn't have to travel to certain distance before business transaction is carried out.

\section{Findings and Discussion}

The study revealed that smart phone recorded the highest adoption 259 (97.7\%), followed by debit card with $104(39.2 \%)$. Encrypted credit card and point-of-sale terminal recorded least adoption 12 (4.5\%) each. only smart phone is properly utilized by Kano based traders, usually for e-payment with response rate of 69 (26.0\%), e-sale with response rate of $21.9 \%$ and sending or receiving purchase order with response rate of $19.6 \%$ and $13.2 \%$ respectively. ATM is partially utilized for making payment only $81(30.6 \%)$ response rate. All other ICTs are either completely unutilized, as in the case of e-wallet or negligibly utilize as in the case of video-conferencing with only $2(0.8 \%)$. Encrypted credit card with $15 \%$ response rate, electronic fund transfer with response rate of only $4.5 \%$ and debit card with response rate of $10.9 \%$ only. ICTs for e-commerce are useful; they make the commerce to be secured, convenient, cheaper etc $133(50 . \%)$ of the respondents believed that e-commerce is better than traditional commerce $81(30.6 \%)$ of the respondents believed that e-commerce is convenient and other $81(30.6 \%)$ believed that e-commerce reduces the cost of transactions compared to bricksand-mortar method.

\section{Conclusion}

From the major findings of the study, it can be concluded that, adoption and utilization of ICTs for ecommerce is very low despite the fact that Kano based Traders believed that e-commerce is better than the traditional commerce in terms of convenience, speed and accuracy and cost effectiveness among others. This in one way or the other affects the implementation of the cashless policy recently introduced by the Central Bank of Nigeria. Hence Kano based traders should adopt and utilise ICTs for effective implementation of Federal Government's cashless policy or they should be left out.

\section{Recommendations}

Base on the major findings of the study, the following recommended are made:

* Mass literacy campaign should be extended to traders, who can not read and write, as the Literate ones should be encouraged to go for computer training. These can be the foundation for proper adoption and utilization of various ICTs used for e-commerce.

* State ministries of commerce in conjunction with Central Bank of Nigeria and traders' unions should organize public enlighten campaign on the need for traders and consumers to go with global trend. The campaign should be centred on the advantages of e-commerce to the entire nation, individual traders and consumers.

* Government in partnership with trades' unions should provide different ICTs for e-commerce such as POS terminals available and affordable to traders.

* Ministries of commerce in conjunction with Central Bank of Nigeria and traders' unions

Should organize Training workshops periodically, to both traders and consumers, on how to utilize and adopt various ICTs for e-payment, e-sale, sending and receiving purchase order e.t.c.

* Governments should provide all infrastructures that can facilitate reliable Internet connectivity and easy access. This should include regular and reliable Power supply, adequate bandwidth among others.

\section{References}

[1]. Settle, A. (2000). A. Survey of e-Commerce Technology. Retrieved from facwed.csdepend.edu/asettle/research/act250/de on 27 April, 2013.

[2]. Christophe, C. (2011). Traditional Commerce vs e-Commerce: 10 key Points to Consider. Retrieved from www.Uky.Edu/indisianita/390wkl.html on $21^{\text {st }}$ September,2012

[3]. World Bank (2002) Information and Communication Technology: A World Bank Group Strategy. USA: World Bank Group.

[4]. World Trade Organisation (2013) e-Commerce in Developing Countries: Opportunities and challenges for small and medium-sized enterprises. Retrieved From http://www.wto.org/english/res_e/booksp_e/ecom_brochure_e.pdf on $11^{\text {th }}$ October, 2014

[5]. Tuban, E., Lee, and Chung (2000).Electronic Commerce: A Managerial Perspective. London: Prentice hall.

[6]. Central Bank of Nigeria (2014). Introduction of Cash-Based Transactions. Retrieved from www.centralbank.org/cashless on 25 September, 2014.

[7]. GSPAY (2012). E-mail E-commerce and Marketing. Retrieved from www.gspay.com/e-mailcommerce-and-marketingph on 19 0ct.2012

[8]. Humphrery, J.R. (2003). The Reality of e-Commerce in Developing Countries. Retrieved from www.eprintsise.ac.uk/37.1011/thereality-of-e-commerce-withdeveloping-countries-pdf on $26^{\text {th }}$ January 2013.

[9]. Angle, I. (2008). The History and Evolution of e-Commerce. Retrieved from http://wwwecomworldpress.com/2008/07/08 thehistory and the evolution of ecommerce on $18^{\text {th }}$ June, 2012. 
[10]. Exforsyst (2012). E-commerce and EDI. Retrieved from www.Exforsyst.com on $6^{\text {th }}$ January, 2013.

[11]. Ssewanyana, J. and Busler, M. (2007). Adoption of ICTs for e-Commerce in Developing Countries: Case of Ugandan Firms. International Journal of education and development using ICTs. Vo1.3 pp. 49-59.

[12]. Egan,J. (2011). "Mobile phone Use" Exploding in e-Commerce. Retrieved from www.technorati.com/technology/article.moblephone-use-exploding on 28th January, 2013.

[13]. Heathcote, P.M. (2002). As Level ICT. London Pane Gallway Publishers Ltd.

[14]. Seatini, R.M (2004). E-commerce and Developing Countriesm: Challenges and Constraint. Retrieved from www.seatin.org/publications/factsheet/ecommerce.htm on 25th Oct,2013.

[15]. UKONS (2011) e-Commerce and ICT activity, 2010 Edition. Retrieved from http://www.ons.gov.uk/ons/res/rditz/ict.activity-of-ukbusinesss/2010/stbe]commerceand-ict-activity-2010.htm/\#tab-over-view on 5th January, 2013.

[16]. Indenscat A. (2002). Use of ICTs and e-Commerce in companies. Retrieved from wwwidensact.cat/pub/?idetice/112\&langen on $11^{\text {th }}$ January, 2012.

[17]. UNCTAD (2013). ICTs and e-Commerce: An opportunity for Developing Countries. Retrieved from www.Unctad.org/en/docs/issmisc 2003 on $28^{\text {th }}$ December, 2013.

[18]. Ayo Charles K. (2006): The Prospects of e-Commerce Implementation in Nigeria, Journal of Internet Banking and Commerce, December 2006, Vol. 11 (3) accessedon $11^{\text {th }}$ October, 2014 from http://www.arraydev.com/commerce/jibcl

[19]. Ghorish, M. (2009). E-commerce adoption Mode in Iranian- SMEs. Masters Thesis. Department of Business Admin and social science. Tehran University.

[20]. Akintola K.G, Akinyede R.O. and Agbonifo C.O. (2011) Appraising Nigeria Readiness for e-commerce towards: Achieving Vision 20: 2020 accessed on $11^{\text {th }}$ October, 2014 from www.arpapress.com/Volumes/Vol9Issue2/IJRRAS_9_2_18.pdf

[21]. Oliva, M. (2011). Differences Between e-Banking and e-Commerce. Retrieved from http://www.differencesbetween-ebankingande-commerce on $27^{\text {th }}$ May, 2013

[22]. Anyakoha, M.N. (2005). Information and Communication Technology (ICT) in Library and Information Service Journal of Information science Vo1. 8 (1\&2). P252-258 